\title{
Effect of Metal Ions and Polyamines on the Development of Bacteriophage $\phi \mathbf{R}$
}

\author{
By R. G. TUCKER \\ Microbiology Unit, Department of Biochemistry, University of Oxford
}

(Received 13 February 1963)

\begin{abstract}
SUMMARY
One-step growth experiments with bacteriophage $\phi \mathbf{R}$ showed that the yield of phage increased with increasing $\mathrm{Mg}^{2+}$ concentration. The function of $\mathrm{Mg}^{2+}$ was not primarily that of a lysis cofactor since the titre of intracellular phage was also dependent upon metal ion concentration. Phage development could be promoted by addition of $\mathrm{Mg}^{2+}$ after the end of the normal latent period. This stimulatory action was not appreciably inhibited by chloramphenicol or respiratory poisons, though it was abolished at low temperature and gradually became less as the time between infection and $\mathrm{Mg}^{2+}$ addition was increased. Qualitatively similar effects on phage growth were obtained with other divalent metal ions and with some polyamines. It is concluded that all these substances act at a late stage in the intracellular development of phage $\phi \mathbf{R}$, possibly at some step involving the neutralization of nucleic acid. Whether or not $\mathrm{Mg}^{2+}$ ions are also required for the release of phage particles cannot be determined from the present experiments, though some of the results suggest that they may be.
\end{abstract}

\section{INTRODUCTION}

Previous observations on the role of $\mathrm{Mg}^{2+}$ in the growth of bacteriophage $\phi \mathbf{R}$ (phage anti-R) have shown that the metal is required at the end of the growth cycle (Tucker, 1961). In the present investigation an attempt was made to determine the nature of this late step, in particular to find out whether it involves an increase in the total number of infectious particles or merely an increased liberation of phage.

\section{METHODS}

Host organism. Escherichia coli strain c (kindly supplied by Dr K. Burton, Department of Biochemistry, University of Oxford) was used throughout the present work. This organism was chosen in preference to Salmonella typhi which had previously been used as the phage host (Tucker, 1961) since it gave better yields of phage.

Phage. Phage $\phi \mathbf{R}$ (Kay, 1962), which has also been called phage anti-R (Fildes, 1954; Kay, 1955; Tucker, 1961), is one of a group of small coliphages containing single-stranded DNA. Lysates of phage $\phi \mathbf{R}$ were prepared in glycerol + casein hydrolysate medium (Fraser \& Jerrel, 1953) from which $\mathrm{CaCl}_{2}$ and gelatin were omitted and to which $4 \times 10^{-3} \mathrm{M}-\mathrm{MgSO}_{4}$ was added after autoclaving $\left(121^{\circ}, 10 \mathrm{~min}\right.$.). The crude lysates, containing $1-2 \times 10^{11}$ plaque-forming units $(\mathrm{pfu}) / \mathrm{ml}$. were purified by a method essentially that of Tromans \& Horne (1961). Phage was assayed by the 
double-layer technique (Adams, 1950) with L-broth (Lennox, 1955) +2.5 $\times 10^{-3} \mathrm{M}$ $\mathrm{CaCl}_{2}+5 \times 10^{-3} \mathrm{M}$-glucose, solidified with 2 and $0.7 \%$ agar (Difco) in the bottom and top layers, respectively.

Media. The chemically defined medium, which will be referred to as 'minimal medium' was that of Kay \& Fildes (1950) used at half strength and supplemented with $0.2 \%(\mathrm{w} / \mathrm{v})$ lactose. The low $\mathrm{Mg}^{2+}$ concentration of this minimal medium $\left(2 \times 10^{-5} \mathrm{M}\right)$ permits only about half the total amount of growth of Escherichia coli $\mathrm{C}$ which is possible when $\mathrm{Mg}^{2+}$ is in excess (greater than $5 \times 10^{-5} \mathrm{M}$ ) but it does not affect the rate of growth.

The buffer used for diluting organisms and phage consisted of minimal medium without $\mathrm{Mg}^{2+}$ and without lactose.

One-step growth experiments. Escherichia coli $\mathrm{c}$ was grown in minimal medium with aeration at $37^{\circ}$ until the viable count reached $4 \times 10^{8}$ organisms $/ \mathrm{ml}$. Five ml. of the culture were centrifuged and the pellet resuspended in $5 \mathrm{ml}$. solution containing $1 \%(\mathrm{w} / \mathrm{v})$ peptone (Evans), $4 \times 10^{-3} \mathrm{M}-\mathrm{MgSO}_{4}$ and $1.5 \times 10^{-4} \mathrm{M}$-chloramphenicol (Parke Davis), and phage $\phi \mathbf{R}$ was added to give a cell:phage ratio of unity. After incubation at $37^{\circ}$ for $10 \mathrm{~min}$. the unadsorbed phage was inactivated by addition of $0.1 \mathrm{ml}$. phage antiserum and incubation for a further $5 \mathrm{~min}$. at $37^{\circ}$. The culture was then diluted in buffer and a suitable volume was transferred to a 1 shaped tube containing minimal medium (growth tube) which was incubated at $37^{\circ}$ with rocking. When necessary, samples were diluted in buffer before plating.

In the experiments that follow the plaques obtained when samples were plated without further treatment, i.e. the plaques from phage particles which were free at the time of plating as well as those from infected bacteria, will be called 'infective centres'. 'Total phage' refers to the plaque count obtained after the release of intracellular phage by artificial lysis. The method of Kohn \& Szybalski (1959) was adapted to give a highly convenient procedure for liberating phage $\phi \mathbf{R}$. Samples $(2.5 \mathrm{ml}$.) were removed from the growth tube and transferred to $110 \times 15 \mathrm{~mm}$. lusteroid centrifuge tubes containing $50 \mu \mathrm{g}$. lysozyme (Armour Pharmaceutical Co. Ltd., Eastbourne, Sussex) and rapidly frozen by plunging into liquid air. After thawing and incubation at $37^{\circ}$ for $5 \mathrm{~min}$. the samples were plated as usual. Control experiments showed that the method gave complete lysis of the organisms as judged by the release of $\beta$-galactosidase, and that it neither destroyed free phage $\phi \mathbf{R}$ nor reactivated phage which had been treated with antiserum.

Materials. Where possible, solutions of metal salts were prepared from Analytical Reagent Grade chemicals. Polyamines were from the following sources: agmatine sulphate, spermidine phosphate, spermine hydrochloride and putrescine hydrochloride from Roche Products Ltd. (Welwyn Garden City, Herts); 1,3-diaminopropane from Light and Co. Ltd. (Colnbrook, Bucks); 1,2-diaminopropane from British Drug Houses Ltd. (Poole, Dorset).

\section{RESULTS}

One step growth experiments with Escherichia coli strain $c$

Cultures of Escherichia coli $\mathrm{c}$, which had been infected with phage in the presence of $4 \times 10^{-3} \mathrm{M}-\mathrm{MgSO}_{4}$ and then diluted into minimal medium, showed only a small increase in the number of infective centres after $60 \mathrm{~min}$. incubation at $37^{\circ}$. Under 
these conditions the intracellular phage count showed a somewhat greater increase, but good phage development, measured either as the increase in the infective centre count or in the intracellular phage count after artificial lysis, required added $\mathbf{M g}^{\mathbf{2}+}$ (Fig. 1). These results are qualitatively the same as those reported ('Tucker, 1961) for another bacterial host, Salmonella typhi, the main difference being the greater intracellular phage development in $E$. coli $\mathrm{c}$ in minimal medium without extra $\mathrm{Mg}^{2+}$.

Figure 2 shows the phage production at $60 \mathrm{~min}$. in a series of one-step growth experiments with different $\mathrm{Mg}^{2+}$ concentrations. The increase in the total phage count with increasing amounts of $\mathrm{Mg}^{2+}$ means that this cation is concerned in the

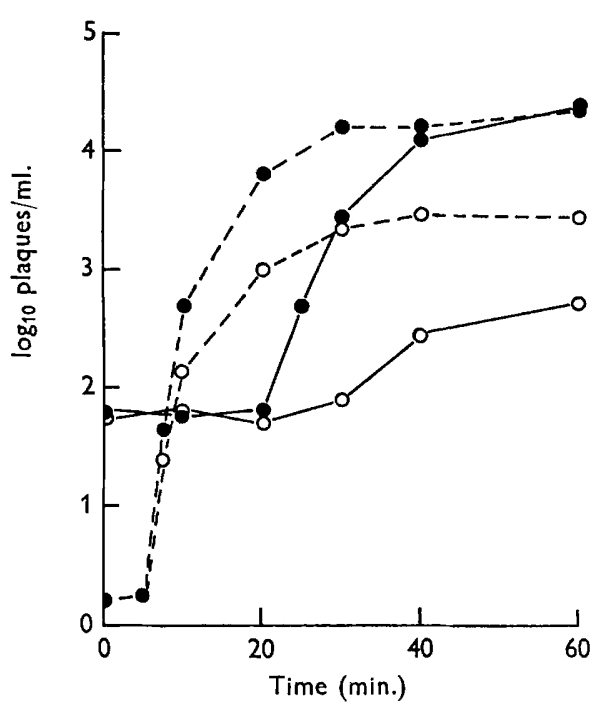

Fig. 1

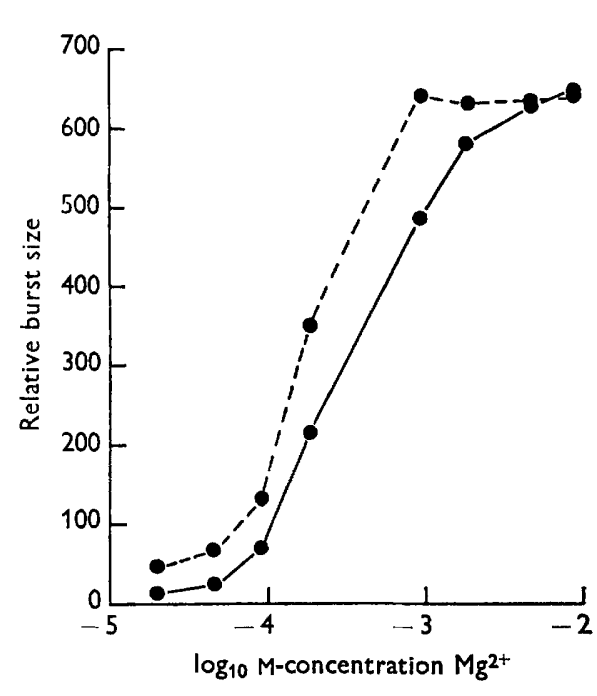

Fig. 2

Fig. 1. Effect of $\mathrm{Mg}^{2+}$ in one-step growth experiments. Escherichia coli $\mathrm{C}$ was infected with phage $\phi \mathrm{R}$ in the presence of $4 \times 10^{-3} \mathrm{M}-\mathrm{MgSO}_{4}$ and $1.5 \times 10^{-4} \mathrm{M}$-chloramphenicol. After inactivation of free phage with antiserum the culture was diluted $1.5 \times 10^{6}$ into minimal medium, without $(\mathrm{O}-\mathrm{O})$ and with $(\bullet-\bullet)$ added $\mathrm{MgSO}_{4}\left(4 \times 10^{-3} \mathrm{M}\right)$. $\mathrm{Phage}^{-}$

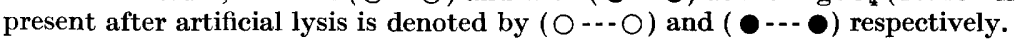

Fig. 2. Effect of $\mathrm{Mg}^{2+}$ concentration on phage yield in one-step growth experiments. Escherichia coli $\mathrm{c}$ was infected with phage $\phi \mathrm{R}$ in the presence of $4 \times 10^{-3} \mathrm{M}-\mathbf{M g S O}_{4}$ and $1.5 \times 10^{-4} \mathrm{M}$-chloramphenicol. Free phage was inactivated with antiserum and the culture was diluted $1.5 \times 10^{6}$ into growth tubes of minimal medium containing varying concentrations of $\mathrm{MgSO}_{4}$. The tubes were assayed at $60 \mathrm{~min}$. for infective centres ( and total phage (---

formation of infectious particles. However, except at the highest concentrations of $\mathrm{Mg}^{2+}$ used the number of infective centres was less than that of total phage, i.e. there was incomplete liberation of phage at $60 \mathrm{~min}$. In experiments in which the phage was assayed at $\mathbf{1 8 0}$ min. after infection a similar dependence of yield of phage upon $\mathrm{Mg}^{2+}$ concentration was found, though the discrepancy between the number of infective centres and the total phage was less marked. 


\section{Effect of delaying the addition of $\mathrm{Mg}^{2+}$ to infected organisms}

The increase in plaque count caused by the late addition of $\mathbf{M g}^{2+}$ which had previously been noted with Salmonella typhi as host was also observed with Escherichia coli $\mathrm{c}$. Thus when a phage-infected culture which had been diluted into minimal medium was supplemented with $4 \times 10^{-3} \mathrm{M}-\mathrm{Mg}^{2+}$ at $40 \mathrm{~min}$. (i.e. $20 \mathrm{~min}$. after the expected end of the latent period) there was a sharp increase in plaque count (Fig. 3). In this experiment the cation produced a fourfold increase in total phage after 5 min., which supports the view that $\mathrm{Mg}^{2+}$ is required for actual phage formation and not merely for the release of preformed infectious particles. Adding $\mathrm{Mg}^{2+}$ late also increased the plaque count of directly-plated samples as well as of those treated with lysozyme, but there was always a lag in phage liberation. The ability of $\mathrm{Mg}^{2+}$ to stimulate phage production was gradually lost on prolonged incubation of infected organisms in minimal medium (Table 1).

\section{Table 1. Effect of time of addition of $\boldsymbol{M g}^{2+}$ on phage $\phi \boldsymbol{R}$ development in Escherichia coli strain $C$}

Escherichia coli $\mathrm{C}$ was infected with phage $\phi \mathrm{R}$ in the presence of $4 \times 10^{-3} \mathrm{M}-\mathrm{MgSO}_{4}+$ $1.5 \times 10^{-4} \mathrm{M}$-chloramphenicol. After inactivation of free phage with antiserum the culture was diluted $1.5 \times 10^{6}$ in minimal medium and assayed periodically for numbers of infective centres and total phage. At 0, 30, 90, 150 and $180 \mathrm{~min}$. after dilution, portions of the culture were transferred to growth tubes containing $4 \times 10^{-3} \mathrm{M}-\mathrm{MgSO}_{4}$ and assayed for infective centres and total phage after 40 min. incubation at $37^{\circ}$.

\begin{tabular}{|c|c|c|c|c|}
\hline \multirow[b]{2}{*}{$\begin{array}{l}\text { Time } \\
\text { (min.) }\end{array}$} & \multicolumn{2}{|c|}{ At time of sampling } & \multicolumn{2}{|c|}{$\begin{array}{r}\text { After } 40 \mathrm{~min} \text {. with } \\
4 \times 10^{-3} \mathrm{M}-\mathrm{MgSO}_{4}\end{array}$} \\
\hline & $\begin{array}{c}\text { Infective } \\
\text { centres }\end{array}$ & $\begin{array}{l}\text { Total } \\
\text { phage }\end{array}$ & $\begin{array}{c}\text { Infective } \\
\text { centres }\end{array}$ & $\begin{array}{l}\text { Total } \\
\text { phage }\end{array}$ \\
\hline & \multicolumn{4}{|c|}{ Plaque counts } \\
\hline $\mathbf{0}$ & 65 & o & 39,500 & 37,000 \\
\hline 30 & 170 & 1700 & 38,400 & 38,100 \\
\hline 60 & 310 & 1350 & - & - \\
\hline 90 & 460 & 1350 & 7,100 & 12,700 \\
\hline 120 & 720 & 2330 & $\ldots$ & - \\
\hline 150 & 530 & 2330 & 2,780 & 5,500 \\
\hline 180 & 730 & 1740 & 980 & 2,730 \\
\hline
\end{tabular}

The increase in the plaque count brought about by $\mathrm{Mg}^{2+}$ was not due to the extracellular activation of non-infective phage material. A phage-infected culture of Escherichia coli $\mathrm{c}$ was washed with buffer then resuspended in minimal medium and incubated at $37^{\circ}$. After assaying the culture for infective centres at $50 \mathrm{~min}$. two volumes were taken and the bacteria in one of them were removed by centrifugation. Magnesium sulphate (to $4 \times 10^{-3} \mathrm{M}$ ) was then added to the supernatant fluid of one sample and to the other uncentrifuged sample. After incubating for $10 \mathrm{~min}$. at $37^{\circ}$ only the sample containing bacteria showed an increase in the number of infective centres. 


\section{Effect of metabolic inhibitors on the action of $\boldsymbol{M g}^{2+}$}

In attempts to determine the mechanism of action of $\mathrm{Mg}^{2+}$ in stimulating phage production, the action of chloramphenicol and of respiratory poisons was investigated. Chloramphenicol $\left(1.5 \times 10^{-4} \mathrm{M}\right)$, potassium cyanide $\left(10^{-2} \mathrm{M}\right)$ or sodium azide $\left(2 \times 10^{-2} \mathrm{M}\right)$ added to a phage-infected culture of Escherichia coli $\mathrm{c}$ immediately after transfer to minimal medium containing $4 \times 10^{-3} \mathrm{M}-\mathrm{Mg}^{2+}$ completely inhibited

Table 2. Effect of chloramphenicol on stimulatory effect of $\mathrm{Mg}^{2+}$ on phage $\phi \boldsymbol{R}$ production

Phage-infected organisms were diluted in minimal medium at $37^{\circ}$. Forty min. after dilution, portions of the culture were transferred to tubes containing $4 \times 10^{-3} \mathrm{M}-\mathrm{MgSO}_{4}$ or $4 \times 10^{-3} \mathrm{M}^{-\mathrm{MgSO}_{4}}+1.5 \times 10^{-4} \mathrm{M}$-chloramphenicol (CAP) and incubated at $37^{\circ}$. At the times indicated the growth tubes were assayed for infective centres and total phage.

\begin{tabular}{|c|c|c|c|c|c|c|}
\hline \multirow[b]{3}{*}{$\begin{array}{l}\text { Time } \\
\text { (min.) }\end{array}$} & & & \multicolumn{4}{|c|}{$4 \times 10^{-3} \mathrm{M}-\mathrm{Mg}^{2+}$ added at $40 \mathrm{~min}$} \\
\hline & \multicolumn{2}{|c|}{ No added $\mathrm{Mg}^{2+}$} & \multicolumn{2}{|c|}{ - CAP } & \multicolumn{2}{|c|}{+ CAP } \\
\hline & $\begin{array}{c}\text { Infective } \\
\text { centres }\end{array}$ & $\begin{array}{l}\text { Total } \\
\text { phage }\end{array}$ & $\begin{array}{c}\text { Infective } \\
\text { centres }\end{array}$ & $\begin{array}{l}\text { Total } \\
\text { phage }\end{array}$ & $\begin{array}{l}\text { Infective } \\
\text { centres }\end{array}$ & $\begin{array}{l}\text { Total } \\
\text { phage }\end{array}$ \\
\hline & \multicolumn{6}{|c|}{ Plaque counts } \\
\hline $\mathbf{0}$ & 112 & 10 & - & 一 & 一 & - \\
\hline 40 & 440 & 1900 & - & 一 & - & - \\
\hline 55 & 一 & - & 38,400 & 66,500 & 4,700 & 59,300 \\
\hline 70 & 一 & 一 & 64,500 & 74,200 & 66,100 & 67,100 \\
\hline 85 & 995 & 4400 & 83,500 & 83,000 & 63,800 & 60,200 \\
\hline
\end{tabular}

phage growth. However, none of these compounds was able to prevent rapid phage development when added with $\mathrm{Mg}^{2+}$ at later times after infection. The results of an experiment with chloramphenicol are given in Table 2 ; both azide and cyanide were very similar in their action though it was consistently noticed that phage release was slower in their presence (Fig. 4). These results imply that the synthesis of protein necessary for phage formation proceeded in the absence of added $\mathrm{Mg}^{2+}$, and that the acquisition of infectivity brought about by the divalent metal was not dependent upon respiratory energy. In contrast to the failure of the above inhibitors to abolish the $\mathbf{M g}^{2+}$ effect, cooling the culture in an ice bath before adding $\mathbf{M g}^{2+}$ prevented the increase of infective centres and of intracellular phage.

\section{Effect of other metal ions and amines on phage development}

Magnesium ions are not unique in stimulating phage formation in the minimal medium; several other divalent metal ions and polyamines also caused an increase in total phage count when added late to phage-infected organisms. The efficiency of different compounds was compared by adding them to infected cultures $40 \mathrm{~min}$. after dilution into minimal medium; chloramphenicol $\left(1.5 \times 10^{-4} \mathrm{M}\right)$ was also added to eliminate the possible complication of continued protein synthesis. After 20 min. incubation in test tubes at $37^{\circ}$ the total number of phage was determined after the addition of lysozyme and freezing. Because of the day-to-day variation in the absolute increase in plaque count with a given substance, a control with $\mathrm{CaCl}_{2}$ $\left(4 \times 10^{-4} \mathrm{M}\right)$ was included routinely, the results being expressed as a percentage of 


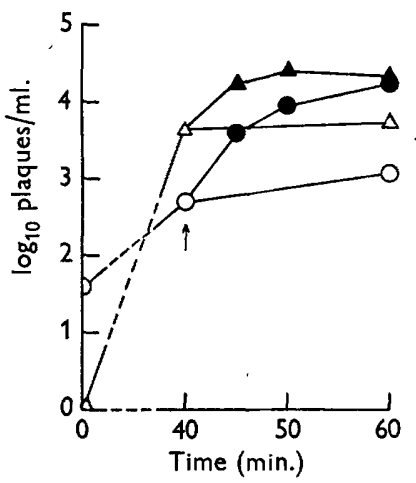

Fig. 3

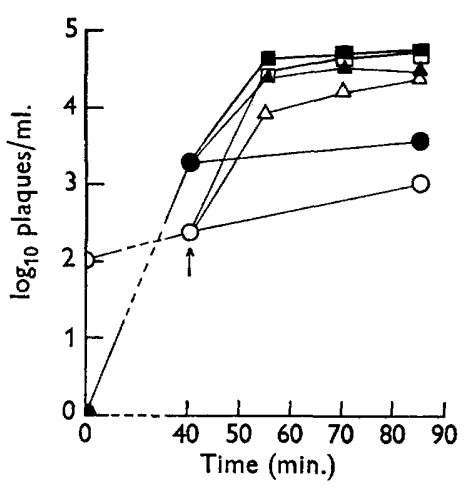

Fig. 4

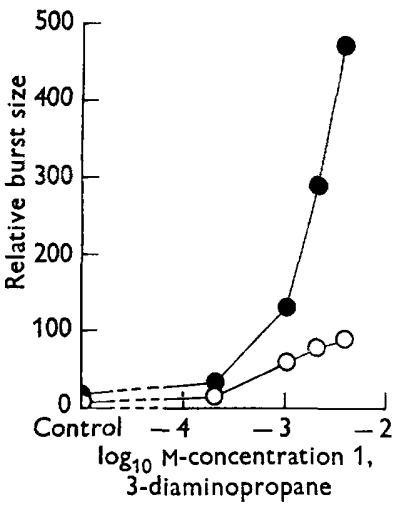

Fig. 5

Fig. 3. Effect of delaying the addition of $\mathrm{Mg}^{2+}$ on phage development. Escherichia coli $\mathrm{C}$ was infected with phage $\phi \mathrm{R}$ in the presence of $4 \times 10^{-3} \mathrm{M}-\mathrm{MgSO}_{4}$ and $1.5 \times 10^{-4} \mathrm{M}$ chloramphenicol. Free phage was inactivated with antiserum and the culture was diluted into minimal medium (infective centres, $O-O$; total phage, $\triangle-\triangle$ ). At 40 min. a portion of the culture was transferred to another growth tube containing $4 \times 10^{-3} \mathrm{M}-\mathrm{MgSO}_{4}$ (infective centres, -0 ; total phage, $\Delta-\Delta$ ).

Fig. 4. Effect of sodium azide on stimulatory effect of $\mathrm{Mg}^{2+}$. Escherichia coli $\mathrm{C}$ was infected with phage $\phi \mathrm{R}$ in the presence of $4 \times 10^{-3} \mathrm{M}-\mathrm{MgSO}_{4}$ and $1.5 \times 10^{-4} \mathrm{M}$-chloramphenicol, and after inactivation of free phage with antiserum the culture was diluted into minimal medium (infective centres, $O-O$; total phage, - - At 40 min. portions of this culture were transferred to two growth tubes containing $4 \times 10^{-3} \mathrm{M}-\mathrm{MgSO}_{4}$ (infective centres, $\square-\square$; total phage, $\square-\square$ ) and $4 \times 10^{-3} \mathrm{M}-\mathrm{MgSO}_{4}+2 \times 10^{-2} \mathrm{M}$-sodium azide (infective centres, $\triangle-\triangle$; total phage, $\Delta-\Delta$ ).

Fig. 5. Effect of 1,3-diaminopropane concentration on phage yield in one-step growth experiments. Escherichia coli $\mathrm{C}$ was infected with phage $\phi \mathrm{R}$ in the presence of $4 \times 10^{-3} \mathrm{M}-$ $\mathrm{MgSO}_{4}$ and $1.5 \times 10^{-4} \mathrm{M}$-chloramphenicol. Free phage was inactivated with antiserum and the culture was diluted into minimal medium containing various amounts of $1,3-$ diaminopropane. The growth tubes were assayed at $60 \mathrm{~min}$. for infective centres $(\mathrm{O}-\mathrm{O})$ and total phage (-o).

\section{Table 3. Effect of late addition of metal ions and polyamines on phage $\phi R$ development in Escherichia coli strain $C$}

Phage-infected $E$. coli $\mathrm{c}$ was diluted in minimal medium and incubated at $37^{\circ}$. After 40 min., samples were transferred to tubes containing the substance under investigation $+1.5 \times 10^{-4} \mathrm{M}$-chloramphenicol. After incubation at $37^{\circ}$ for $20 \mathrm{~min}$. the total phage in the tubes was assayed after artificial lysis. Metal salts at $4 \times 10^{-4} \mathrm{M}$; polyamines at $4 \times 10^{-3} \mathrm{M}$.

Titre $\times 100$

Substance Titre with $4 \times 10^{-4} \mathrm{M}-\mathrm{Ca}^{2+}$
Titre $\times 100$ Titre with $4 \times 10^{-4} \overline{\mathrm{M}-\mathrm{Ca}^{2+}}$

$\begin{array}{lr}\mathrm{None}_{\mathrm{CaCl}} & \mathbf{1 2} \\ \mathrm{SrCl}_{2} & 100 \\ \mathrm{MgSO}_{4} & \mathbf{8 8} \\ \mathrm{BaCl}_{2} & \mathbf{8 4} \\ \mathrm{MnCl}_{2} & \mathbf{7 9} \\ \mathrm{CdCl}_{2} & \mathbf{7 4} \\ \mathrm{CoSO}_{4} & \mathbf{7 1} \\ \mathrm{NiCl}_{2} & \mathbf{7 0} \\ \mathrm{BeCl}_{2} & \mathbf{5 4} \\ & 41\end{array}$

Agmatine

1,3-Diaminopropane $\quad 99$

Spermidine $\quad \mathbf{7 2}$

1,2-Diaminopropane $\quad 57$

Spermine $\quad 56$

Putrescine $\quad 34$

$\mathrm{CaCl}_{2}+\mathrm{MgSO}_{4} \quad \mathbf{1 0 6}$

$\mathrm{CaCl}_{2}$ + agmatine $\quad 90$

$\mathrm{CaCl}_{2}+$ 1,3-diaminopropane 110 
the titre obtained after $20 \mathrm{~min}$. exposure to $\mathrm{Ca}^{2+}$. Data from a number of experiments are given in Table 3 . No appreciable increase in phage titre was obtained with $\mathrm{NaCl}$ or $\mathrm{LiCl}$ over the range $7.5 \times 10^{-2} \mathrm{M}$ to $3 \times 10^{-1} \mathrm{M}$, with zinc acetate $\left(4 \times 10^{-4} \mathrm{M}\right)$ or with ferrous sulphate $\left(4 \times 10^{-4} \mathrm{M}\right)$.

The substances tested in Table 3 also increased the plaque count of samples plated without artificial lysis though they were not equally active in this respect. 1,3-Diaminopropane in particular caused only a small increase in the number of infective centres in spite of its being one of the most active of the amines in stimulating phage development. One-step growth experiments with organisms infected in the presence of $\mathrm{Mg}^{2+}+$ chloramphenicol and subsequently diluted into minimal medium containing various concentrations of 1,3-diaminopropane also showed that there was relatively poor phage release with this compound (Fig. 5). The addition of $\mathrm{Mg}^{2+}$ at $40 \mathrm{~min}$. to similar cultures in $4 \times 10^{-3} \mathrm{M}$-1,3-diaminopropane resulted in an increase in the number of infective centres (Table 4) which may indicate that phage release has a specific requirement for the metal ion.

Table 4. Effect of adding $M g^{2+}$ to phage $\phi R$-infected Escherichia coli strain $c$ in medium containing 1,3-diaminopropane

\begin{abstract}
- A culture of Escherichia coli $\mathrm{C}$ was infected with phage $\phi \mathbf{R}$ in the presence of $4 \times 10^{-3} \mathrm{M}$ $\mathrm{MgSO}_{4}+1.5 \times 10^{-4} \mathrm{M}$-chloramphenicol. The culture was diluted $1 / 5 \times 10^{6}$ in minimal medium containing $4 \times 10^{-3} \mathrm{M}-1,3$-diaminopropane and incubated at $37^{\circ}$. After $40 \mathrm{~min}$. a portion of the culture was supplemented with $4 \times 10^{-3} \mathrm{M}-\mathrm{MgSO}_{4}$ and assayed for number of infective centres and total phage after a further $20 \mathrm{~min}$. incubation.
\end{abstract}

\begin{tabular}{|c|c|c|c|c|}
\hline \multirow[b]{2}{*}{$\begin{array}{l}\text { Time } \\
\text { (min.) }\end{array}$} & \multicolumn{2}{|c|}{ No addition } & \multicolumn{2}{|c|}{$4 \times 10^{-3} \mathrm{M}-\mathrm{Mg}^{2+}$ at $40 \mathrm{~min}$} \\
\hline & $\begin{array}{l}\text { Infective } \\
\text { centres }\end{array}$ & $\begin{array}{l}\text { Total } \\
\text { phage }\end{array}$ & $\begin{array}{c}\text { Infective } \\
\text { centres }\end{array}$ & $\begin{array}{l}\text { Total } \\
\text { phage }\end{array}$ \\
\hline & \multicolumn{4}{|c|}{ Plaque counts } \\
\hline 0 & 44 & 0 & - & - \\
\hline 40 & 3,200 & 19,700 & 一 & $\ldots$ \\
\hline 60 & 6,300 & 24,800 & 16,900 & 20,700 \\
\hline
\end{tabular}

\title{
DISCUSSION
}

The dependence of the intracellular phage $\phi \mathbf{R}$ concentration upon $\mathrm{Mg}^{2+}$ concentration, and the increase in intracellular phage titre when $\mathbf{M g}^{2+}$ was added late to infected Escherichia coli $\mathrm{c}$ show clearly that $\mathbf{M g}^{2+}$ is needed for some step in the development of the phage. Since neither chloramphenicol nor respiratory inhibitors appreciably affected the stimulatory action of the late addition of $\mathrm{Mg}^{2+}$, it is concluded that synthesis of components of phage $\phi \mathbf{R}$ can proceed in the absence of added $\mathrm{Mg}^{2+}$ and that higher concentrations of $\mathrm{Mg}^{2+}$ are needed for some terminal event in the growth of the phage leading to an increase in the number of infectious particles. Without knowledge about the immediate precursor of mature phage $\phi \mathbf{R}$ the nature of this step must remain unknown, though the qualitatively similar effects of other divalent metals and of polyamines suggest that neutralization of nucleic acid charge may be involved. These substances can neutralize'and stabilize nucleic acids in vitro (Felsenfeld \& Huang, 1960; Tabor, Tabor \& Rosenthal, 1961; Eichhorn, 1962) and it is believed that they function similarly in some phages (Ames, Dubin \& Rosenthal, 1958; Kay, 1959; Ames \& Dubin, 1960). The idea that the 
cations diffuse into and neutralize the nucleic acid of structurally completed phage $\phi \mathrm{R}$ particles is an attractive explanation of the observed results. However, if this be so, some further change in the particles has to be postulated to account for the failure to obtain the effect of the metals once the cells have been lysed and for the fact that free phage is stable in the presence of chelating agents.

The present experiments do not permit a decision about whether or not the cations are also concerned in phage liberation. In one-step growth experiments with $4 \times 10^{-3} \mathrm{M}-\mathrm{Mg}^{2+}$ present from the beginning of infection lysis appeared to be complete by $60 \mathrm{~min}$.; the ability of $\mathrm{Mg}^{2+}$ to stimulate phage production when added as late as $\mathbf{1 5 0} \mathrm{min}$. after infection might therefore be explained if phage release was slower or incomplete in the whole culture without added cations. Some support for this comes from experiments where $\mathrm{Mg}^{2+}$ increased the number of infective centres of cultures incubated with 1,3-diaminopropane (Table 4), and from the observation (Tucker, 1961) that the number of infective centres did not increase when $\mathrm{Mg}^{2+}$ was removed by chelation during the rising period of phage growth.

I am much indebted to Mrs W. Smith for technical assistance. The work was aided by grants to the Department from the Rockefeller Foundation and the United States Department of Health, Education and Welfare.

\section{REFERENCES}

Adams, M. H. (1950). Methods of study of bacterial viruses. Meth. Med. Res. 2, 1.

Ames, B. N. \& Dubin, D. T. (1960). The role of polyamines in the neutralization of bacteriophage deoxyribonucleic acid. J. biol. Chem. 235, 569.

Ames, B. D., Dubin, D. T. \& Rosenthal, S. M. (1958). Presence of polyamines in certain bacterial viruses. Science, $127,814$.

EichionN, G. L. (1962). Metal ions as stabilizers or destabilizers of the deoxyribonucleic acid structure. Nature, Lond. 194, 474.

Felsenfeld, G. \& Huang, S. (1960). The interaction of polynucleotides with metal ions, amino acids and polyamines. Biochem. biophys. Acta, 37, 425.

Fildes, P. (1954). 'The relation of divalent metals to lysis of typhoid bacilli by bacteriophages. Brit. J. exp. Path. 35, 122.

Fraser, D. \& Jerrel, E. A. (1953). The amino acid composition of T3 bacteriophage. J. biol. Chem. 205, 291.

KAY, D. (1955). The reactions of certain bacteriophages with their receptors isolated from Salmonella typhi 0901 R. Brit. J. exp. Path. 36, 290.

KAX, D. (1959). The inhibition of bacteriophage multiplication by proflavine and its reversal by certain polyamines. Biochem. J. 73, 149.

KAY, D. (1962). The nucleic acid composition of bacteriophage $\phi$ R. J. gen. Microbiol. 27, 201.

KAY, D. \& Fildes, P. (1950). The calcium requirement of a typhoid bacteriophage. Brit. J. exp. Path. 31, 338.

Kohn, A. \& Szybalski, W. (1959). Lysozyme spheroplasts from thawed Escherichia coli cells. Bact. Proc. p. 126.

LEnnox, E. S. (1955). Transduction of linked genetic characters of the host by bacteriophage P1. Virology, 1, 190.

Tabor, H., Tabor, C. W. \& Rosenthal, S. M. (1961). The biochemistry of the polyamines: spermidine and spermine. Ann. Rev. Biochem. 30, 579.

Tromans, W. J. \& Horne, R. W. (1961). The structure of bacteriophage $\phi$ X 174. Virology, $15,1$.

Tucker, R. G. (1961). The role of magnesium ions in the growth of Salmonella phage anti-R. J. gen. Microbiol. 26, 313. 